\title{
Efek Sitotoksik Protein dari Daun Mirabilis jalapa L. Hasil Pemurnian dengan kolom CM Sepharose CL-6B terhadap Kultur Sel HeLa
}

\author{
Ni Putu Ariantari ${ }^{1 *}$, Zullies Ikawati², Sudjadi $^{2}$, Sismindari $^{2}$ \\ ${ }^{1}$ Jurusan Farmasi Fakultas Matematika dan Ilmu Pengetahuan Alam Universitas Udayana \\ ${ }^{2}$ Fakultas Farmasi Universitas Gadjah Mada \\ alamat korespondensi*: ari_dedhika@yahoo.com
}

\begin{abstract}
Mirabilis jalapa L. leaves have been known containing Ribosome Inactivating Proteins (RIPs) base on its $N$-glycosidase activity and cleavage of supercoiled double stranded DNA. The research aims to investigate cytotoxic activity of protein isolated from Mirabilis jalapa $L$. leaves against HeLa cell culture. In this research, crude extract of Mirabilis jalapa L. leaves was separated by gradual precipitation using sulphate ammonium followed by dyalisis. Further separation of protein fraction with cation exchange chromatography using CM Sepharose CL-6B column and elution with sodium phosphate buffer $5 \mathrm{mM}$ pH 6,5 for 30 minutes continued with sodium phosphate buffer $5 \mathrm{mM}$ pH 6,5 containing 0-0,5 M NaCl by gradient elution for 90 minutes. Cytotoxicity activity testing of protein fraction that showed an ability to cleave supercoiled double stranded DNA revealed that RIPs eluated at NaCl gradient of 0.33-0.37 M and 0.38-0.41 M, concentration of $0.553 \mathrm{mg} / \mathrm{mL}$ rrelatively less toxic against HeLa cell culture with percentage of cytotoxicity of $29,53 \%$.
\end{abstract}

Keywords: Mirabilis jalapa L., RIPs, cytotoxicity

\section{Pendahuluan}

Kanker merupakan suatu penyakit sel, dengan ciri adanya gangguan atau kegagalan mekanisme pengatur multiplikasi dan fungsi homeostatis lainnya pada organisme multiseluler. Di negara maju yang telah berhasil membasmi penyakit infeksi, kanker merupakan penyebab kematian kedua, setelah penyakit kardiovaskuler (Heyzer et al., 1987).

Saat ini, telah banyak dikembangkan senyawa kimia baru yang ditelusuri dari bahan alam, yang secara tradisional dikenal berkhasiat sebagai obat. Salah satu senyawa bioaktif dari tanaman yang diindikasikan sebagai antikanker adalah Ribosome Inactivating Proteins (RIPs). Terdapat 2 tipe RIPs yaitu RIPs tipe 1 dan tipe 2. RIPs merupakan protein toksik dari tanaman dengan aktivitas RNA N-glikosidase yang mampu mendepurinasi rRNA sehingga bisa merusak ribosom dan menghentikan sintesis protein. Selama ini, RIPs diketahui memiliki beberapa aktivitas biolois antara lain aktivitas imunosupresif, abortifacient, antiviral, sitotoksisitas pada sel mamalia dan aktivitas pemotongan DNA superkoil untai ganda. Ketertarikan pada RIPs dewasa ini meningkat, karena potensinya untuk dirakit menjadi suatu imunotoksin sehingga dapat dikembangkan sebagai antikanker (Barbieri et al., 1993).

Vivanco et al. (1999) melaporkan bahwa akar dan daun Mirabilis jalapa L yang terdapat di Peru mengandung protein antiviral yang aktif melawan transmisi mekanik Tobacco Mosaic Virus (TMV) pada tembakau, tomat dan lada. Protein tersebut termasuk RIPs tipe 1 yaitu Mirabilis Antiviral Protein (MAP). MAP juga terbukti mampu menghambat sintesis protein Escherichia coli sama baiknya seperti hambatannya pada sel eukariota (Habuka et al., 1999). Berdasarkan penelitian sebelumnya, diketahui bahwa fraksi protein hasil dialisis dari ekstrak daun Mirabilis jalapa L. mampu memotong DNA superkoil untai ganda menjadi nicked circular dan linier serta bersifat sitotoksik terhadap kultur sel HeLa (Elly, 2000) dan kultur sel Raji (Sari, 2002). Protein murni dari daun Mirabilis jalapa L. yang diperoleh melalui pengendapan bertingkat dengan amonium sulfat dan dilanjutkan dengan kromatografi penukar kation menggunakan kolom $C M$ Sepharose $\mathrm{Cl}-6 \mathrm{~B}$ diketahui mempunyai 
aktivitas memotong DNA superkoil pUC18 (Herawati, 2002) dan aktivitas N-glikosidase terhadap Saccharomyces cerevisiae (yeast) (Prasetyowati, 2002). Akan tetapi belum diketahui apakah protein hasil pemurnian tersebut mempunyai aktivitas sitotoksik terhadap sel HeLa. Dalam penelitian ini dilakukan pemurnian dengan kromatografi penukar kation menggunakan kolom $C M$ Sepharose CL-6B untuk menentukan protein spesifik yang memiliki aktivitas mirip RIPs dan aktivitas sitotoksiknya terhadap sel HeLa.

\section{Metode Penelitian \\ Bahan Penelitian}

Semua bahan kimia yang digunakan mempunyai kualitas pro analisis. Bahan tanaman yang digunakan adalah daun Mirabilis jalapa L. segar, varietas bunga merah keunguan yang tumbuh di daerah Samirono, Sleman Yogyakarta. Determinasi daun Mirabilis jalapa L. telah dilakukan di laboratorium Biologi Farmasi Fakultas Farmasi UGM Yogyakarta.

Bahan untuk ekstraksi dan pemurnian: natrium fosfat, $\mathrm{NaCl}$, ammonium sulfat dan CM Sepharose Cl-6B. Bahan untuk uji aktivitas pemotongan DNA superkoil untai ganda: Agarosa (Gibco BRL), larutan TBE $5 \mathrm{X}$ : tris borat $0,445 \mathrm{M}$, asam borat $0,445 \mathrm{M}$, EDTA 0,01M pH 8,0; ethidium bromida (Sigma); dapar pemuat: silensilanol (Sigma) $0,25 \%$ v/v, biru brom fenol (Sigma) 0,25\% v/v, gliserol $30 \% \mathrm{v} / \mathrm{v}$; larutan dpar TMN: tris klorida $50 \mathrm{mM} \mathrm{pH} \mathrm{8,0,} \mathrm{magnesium} \mathrm{klorida}$ $10 \mathrm{mM}$ dan $\mathrm{NaCl} 100 \mathrm{mM}$. Bahan untuk uji sitotoksisitas: kultur sel HeLa diperoleh dari stok Laboratorium Ilmu Hayati UGM; media RPMI 1640: RPMI 1640 (Sigma), natrium bikarbonat dan hepes; Media kultur sel: media RPMI 1640, Fetal bovine serum (Gibco) 10\% v/v, penisilin-streptomisin (Gibco 1\% v/v dan fungison (Gibco) 0,5\% (v/v); MTT; reagen stopper: natrium dodesil sulfat $10 \%$ v/v dalam $\mathrm{HCl} 0,01 \mathrm{~N}$.

\section{Alat Penelitian}

Alat-alat gelas, bejana elektroforesis iMupid.J, incubator orbital shaker (LM510R), vortex (Genie-2), $\mathrm{pH}$ meter (TOA), kolom (tipe $\mathrm{C}$ dimensi $1 \times 20 \mathrm{~cm}$, Pharmacia LKB Biotech), pompa (Perkin Elmer seri 200 LC Pump), detektor (Perkin Elemer UV LV 295), integrator (Perkin Elmer Nelson LC model 1022), ijektor (perkin Elmer oven
101), 96-well plate, ELISA Reader SLT 340

ATC.

\section{Langkah Penelitian \\ Isolasi DNA plasmid pUC18}

Seratus ìl bakteri Escherichia coli DH5á yang membawa plasmid pUC18 dalam gliserol 50\% ditumbuhkan ke dalam $50 \mathrm{ml}$ media LB cair yang mengandung ampisilin $100 \mathrm{ìg} / \mathrm{ml}$ media kemudian diinkubasi dalam incubator orbital shaker pada suhu $37^{\circ} \mathrm{C}$ selama semalam. Kultur hasil inkubasi disentrifugasi dengan kecepatan 2500xg selama 10 menit. Supernatan dibuang, pellet disuspensikan dalam 1,25 ml larutan Lisis I dingin dan digojog, didiamkan dalam es selama 5 menit. Selanjutnya ditambahkan 2,5 ml larutan Lisis II yang dibuat baru (campuran $\mathrm{NaOH}$ 0,2 $\mathrm{N}$ dan SDS 2\% sama banyak) dan digojog perlahan, didiamkan dalam es selama 5 menit. Setelah itu ditambahkan 1,875 $\mathrm{ml}$ larutan Lisis III dingin dan digojog, didiamkan dalam es selama 5 menit. Kemudian disentrifugasi dengan kecepatan $3500 x \mathrm{x}$ selama 10 menit. Supernatan diambil, dipindahkan ke dalam tabung konikal steril, kedalamnya ditambahkan larutan pengekstraksi (terdiri dari campuran fenol : kloroform : isoamilalkohol $=25: 24: 1$ ) sama banyak dengan volume supernatan. Selanjutnya divortex selama 1 menit kemudian disentrigugasi dengan kecepatan 3500xg selama 10 menit. Fase cair paling atas diambil, dipindahkan ke dalam tabung konikal baru dan ditambah dengan kloroform sama banyak dengan volume supernatant, lalu divortex selama 1 menit dan disentrigugasi dengan kecepatan 3500xg selama 10 menit maka akan terbentuk dua fase yaitu fase air dan fase kloroform. Fase air dipisahkan dan dipindahkan ke dalm eppendorf masing-masing 500 ìl. Kemudian masing-masing eppendorf ditambahkan 50 il natrium asetat $3 \mathrm{M} \mathrm{pH} \mathrm{4,8} \mathrm{(1/10} \mathrm{x} \mathrm{volume)}$ dan etanol absolute sebanyak 1,0 ml (2xvolume). Kemudian didiamkan pada suhu $-20^{\circ} \mathrm{C}$. Setelah $1 \mathrm{jam}$ disentrifugasi dengan kecepatan $12.000 x \mathrm{xg}$ selama 10 menit. Supernatan dibuang dan pelet dikeringkan dalam blower suhu $37^{\circ} \mathrm{C}$ selama 15 menit. Pelet yang telah dikeringkan dilarutkan dalam larutan TE pH 7,4 dan disimpan pada suhu $4^{\circ} \mathrm{C}$ semalam. Setelah itu dipindahkan dan disimpan pada suhu $-20^{\circ} \mathrm{C}$. DNA plasmid yang diperoleh dicek dengan 
elektroforesis dalam agarosa $0,8 \% \mathrm{~b} / \mathrm{v}$. Delapan ìl (16,8 ìg) DNA plasmid pUC18 dan 2,0 ìl loading buffer dicampur dan dimasukkan ke dalam sumuran agarosa. Elektroforesis dilakukan dengan kekuatan 50 Volt selama 60 menit dengan menggunakan larutan dapar TBE 0,5x. RNA dihilangkan dengan cara ditambah RNAse $10 \mathrm{ìg} / \mathrm{ml}$ sebanyak $1 / 10 \mathrm{x}$ volume DNA plasmid pUC18 dan diinkubasi pada $37^{\circ} \mathrm{C}$ selama 1 jam.

\section{Ekstraksi dan fraksinasi protein dari daun Mirabilis jalapa $\mathbf{L}$.}

Daun Mirabilis jalapa L. dikumpulkan segar, dicuci bersih dengan air mengalir, lalu dipotong kecil-kecil. Sebanyak 60 gram ditempatkan pada mortar steril, ditumbuk halus dengan penambahan $130 \mathrm{ml}$ dapar natrium fosfat $5 \mathrm{mM} \mathrm{pH} \mathrm{7,2} \mathrm{yang}$ mengandung $0,14 \mathrm{M}$ natrium klorida pada suhu $4^{\circ} \mathrm{C}$. Supernatan pada suhu $4^{\circ} \mathrm{C}$ ditambah ammonium sulfat dengan kejenuhan $40 \%$ sambil diaduk dan didiamkan pada suhu $4^{\circ} \mathrm{C}$ selama 2 jam. Larutan disentrifugasi $3500 x g$ selama 10 menit pada suhu $4^{\circ} \mathrm{C}$. Supernatan kemudian ditambah lagi ammonium sulfat sehingga mencapai kejenuhan $80 \%$, didiamkan selama satu malam pada suhu $4^{\circ} \mathrm{C}$. Larutan itu kemudian disentrifugasi pada $3500 x$ g selama 10 menit pada suhu $4^{\circ} \mathrm{C}$. Supernatan dibuang dan endapan dilarutkan dalam sedikit mungkin dapar natrium fosfat $5 \mathrm{mM} \mathrm{pH} \mathrm{6,5.}$ Selanjutnya dilakukan dialisis semalam menggunakan dapar natrium fosfat $5 \mathrm{mM} \mathrm{pH}$ 6,5. Cairan dialisis diganti 3-4 kali kemudian hasil dialisis disentrifugasi 3500xg selama 10 menit pada suhu $4^{\circ} \mathrm{C}$. Endapan dibuang dan supernatan merupakan sampel fraksi protein.

\section{Pemurnian protein dengan kolom $C M$ Sepharose CL-6B}

Satu $\mathrm{ml}$ fraksi protein hasil dialisis $(21,51 \mathrm{mg})$ diinjeksikan ke dalam kolom yang telah diekuilibrasi dan dielusi dengan dapar natrium fosfat $5 \mathrm{mM} \mathrm{pH} \mathrm{6,5} \mathrm{selama}$ 30 menit dengan kecepatan alir $0,8 \mathrm{ml} / \mathrm{menit}$. Fraksi protein dikoleksi setiap 2 menit dan ditampung ke dalam eppendorf. Protein yang terikat pada fase diam dielusi dengan dapar natrium fosfat $5 \mathrm{mM} \mathrm{pH} \mathrm{6,5} \mathrm{yang}$ mengandung natrium klorida $0,5 \mathrm{M}$ secara bergradien selama 90 menit. Fraksi-fraksi protein yang ditampung diuji aktivitas pemotongan DNA superkoil. Pengukuran kadar protein total dilakukan dengan cara mengambil sebanyak 20,0 il ekstrak gubal, fraksi protein $40 \%$ dan $80 \%$, protein hasil dialisis dan fraksi protein hasil kolom, dan ditambahkan dapar natrium fosfat $5 \mathrm{mM} \mathrm{pH}$ 6,5 sampai volume 1,0 ml, kemudian diukur serapannya dengan spektrofotometer UV pada panjang gelombang 280 dan $260 \mathrm{~nm}$ menggunakan blanko dapar natrium fosfat 5 $\mathrm{mM}$ pH 6,5. Selanjutnya harga R280/260 diekstrapolasikan pada tabel untuk mengetahui besarnya faktor koreksi.

Kadar protein total $(\mathrm{mg} / \mathrm{ml})=\mathrm{A} 280 \mathrm{x}$ faktor koreksi $\mathrm{x}$ faktor pengenceran

\section{Uji aktivitas pemotongan DNA superkoil}

Tiga ìl (6,3 ìg) DNA plasmid pUC18 dicampur dengan 2,5 il dapar TMN 10x pH 8,0 dan fraksi protein dengan kadar tertentu, ditambahkan aqua destilata hingga volume akhir 25,0 ill, diinkubasi pada suhu $30^{\circ} \mathrm{C}$ selama satu jam. Kemudian ditambahkan 2,0 ì dapar pemuat (loading buffer) dan dielektroforesis menggunakan gel agarosa $0,8 \%$ yang mengandung pewarna ethidium bromida dengan kekuatan 50 Volt selama 80 menit menggunakan dapar TBE $0,5 \mathrm{x}$. Pengamatan dilakukan dibawah sinar UV. Uji sitotoksisitas menggunakan metode MTT

Sel HeLa didistribusikan ke dalam sumuran dan diinkubasikan bersama fraksi protein dengan satu seri kadar selama 24 jam. Pada akhir inkubasi, kepada masing-masing sumuran ditambahkan 10 ì MTT $5 \mathrm{mg} / \mathrm{ml}$ dalam medium RPMI. Kemudian diinkubasi lagi selama 4 jam pada suhu $37^{\circ} \mathrm{C}$. Sel yang hidup akan bereaksi dengan MTT membentuk warna ungu. Reaksi MTT dihentikan dengan pereaksi penghenti (stopper) sebanyak 100 ìl dan diinkubasikan semalam pada suhu kamar. Serapan dibaca dengan ELISA reader pada panjang gelombang $550 \mathrm{~nm}$.

\section{Analisis Data}

Persentase kematian sel merupakan selisih jumlah sel kontrol dengan jumlah sel perlakuan dibagi dengan jumlah sel kontrol dikalikan $100 \%$

\section{Hasil Penelitian}

Proses ekstraksi daun segar L. dengan natrium fosfat $5 \mathrm{mM} \mathrm{pH} \mathrm{7,2} \mathrm{yang}$ mengandung 0,14 M natrium klorida pada 
suhu $4^{\circ} \mathrm{C}$ menghasilkan sekitar $155,5 \mathrm{ml}$ ekstrak gubal. Berdasarkan perhitungan, kadar protein ekstrak gubal yang diperoleh sebesar $76,26 \mathrm{mg} / \mathrm{ml}$ sehingga jumlah protein total ekstrak gubal sebesar 11858,43 mg (19,76\% protein dari 60 gram daun). Kadar protein hasil pengendapan dengan ammonium sulfat sampai kejenuhan $40 \%$ sebesar 44,91 mg/ml sedangkan kadar protein pada supernatan setelah penambahan ammonium sulfat sampai kejenuhan $80 \%$ sebesar $8,9 \mathrm{mg} / \mathrm{ml}$. kation menggunakan kolom CM Sepharose CL-6B dan fase gerak dapar natrium fosfat $5 \mathrm{mM}$ pH 6,5 selama 30 menit dengan kecepatan alir $0,8 \mathrm{ml} / \mathrm{menit}$ dilanjutkan elusi dengan dapar natrium fosfat $5 \mathrm{mM} \mathrm{pH} \mathrm{6,5}$ yang mengandung natrium klorida $0,5 \mathrm{M}$ secara bergradien selama 90 menit. Profil kromatogram ditunjukkan pada gambar 1 . Fraksi protein yang terelusi dengan fase gerak dapar natrium fosfat $5 \mathrm{mM} \mathrm{pH} 6,5$

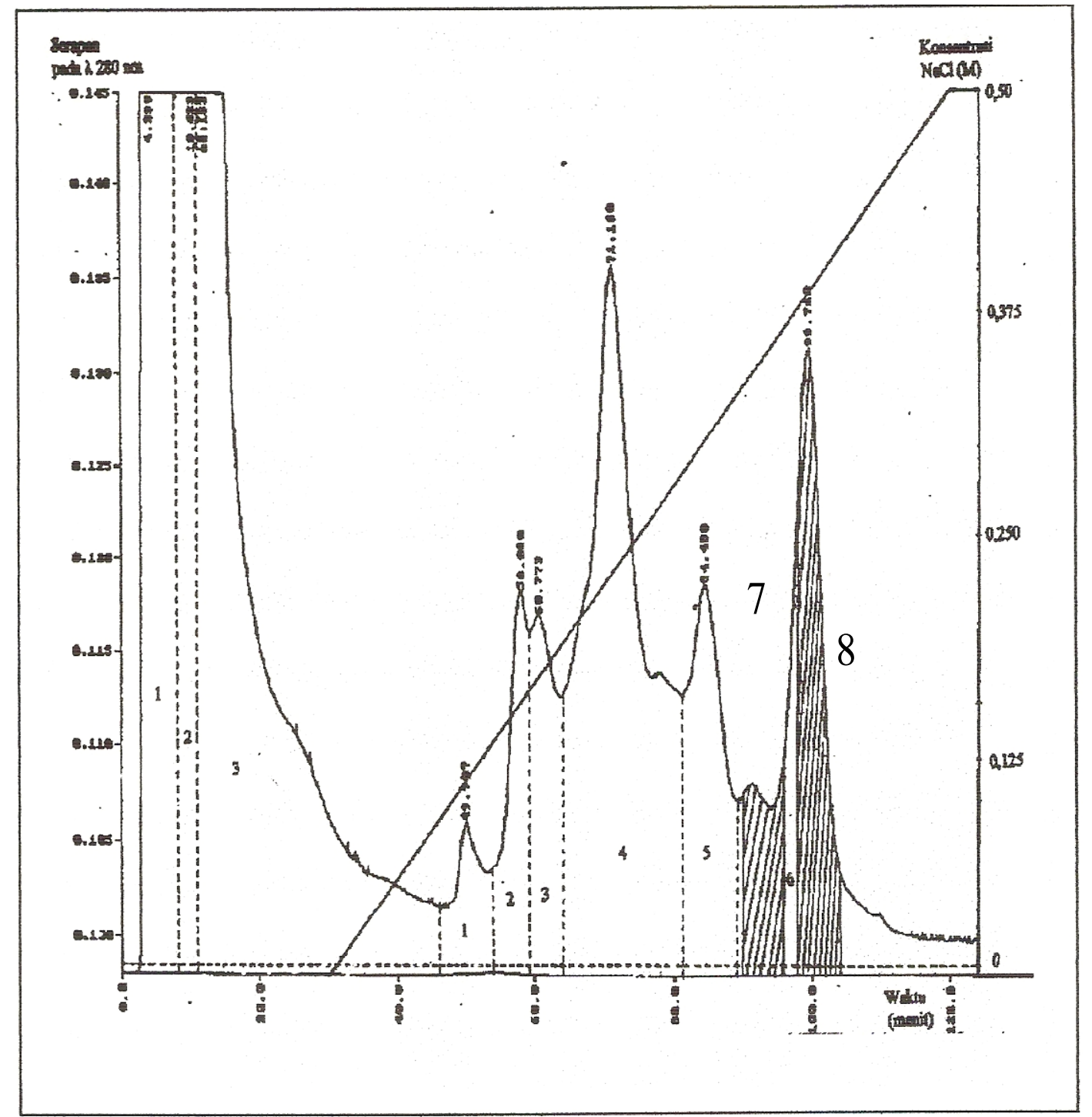

Gambar 1. Profil elusi kromatografi dengan kolom CM Sepharose CL-6B, fraksi dikoleksi setiap 2 menit. Daerah yang diarsir (fraksi 46-48) dan fraksi 50-52) menunjukkan aktivitas pemotongan DNA superkoil

Kadar protein hasil dialisis sebesar $12,51 \mathrm{mg} / \mathrm{ml}$, volume sekitar $14 \mathrm{ml}$ sehingga jumlah protein total sebesar $301,14 \mathrm{mg}$. Fraksi protein hasil dialisis selanjutnya dimurnikan dengan kromatografi penukar selanjutnya disebut fraksi protein tidak terikat fase diam dan fraksi protein yang terelusi dengan fase gerak dapar natrium fosfat $5 \mathrm{mM} \mathrm{pH} 6,5$ yang mengandung natrium klorida $0,5 \mathrm{M}$ secara bergradien disebut fraksi protein terikat fase diam. 
Fraksi protein yang keluar pada puncak yang sama pada kromatogram digabungkan. Dari hasil penggabungan, diperoleh 3 fraksi mayor yang tidak terikat fase diam dan 8 fraksi mayor yang terikat fase diam. Terhadap fraksi-fraksi yang ditampung selanjutnya dilakukan uji aktivitas pemotongan DNA superkoil. protein tersebut terelusi dengan dapar natrium fosfat $5 \mathrm{mM}$ pH 6,5 pada gradien $\mathrm{NaCl} 0,33-0,37 \mathrm{M}$. Selain itu juga diperoleh 2 fraksi mayor yang tidak terikat pada fase diam yang menunjukkan aktivitas pemotongan DNA superkoil yaitu fraksi 2 dan fraksi 3 (gambar tidak ditampilkan).

\section{a $\quad$ b $c c c c$}

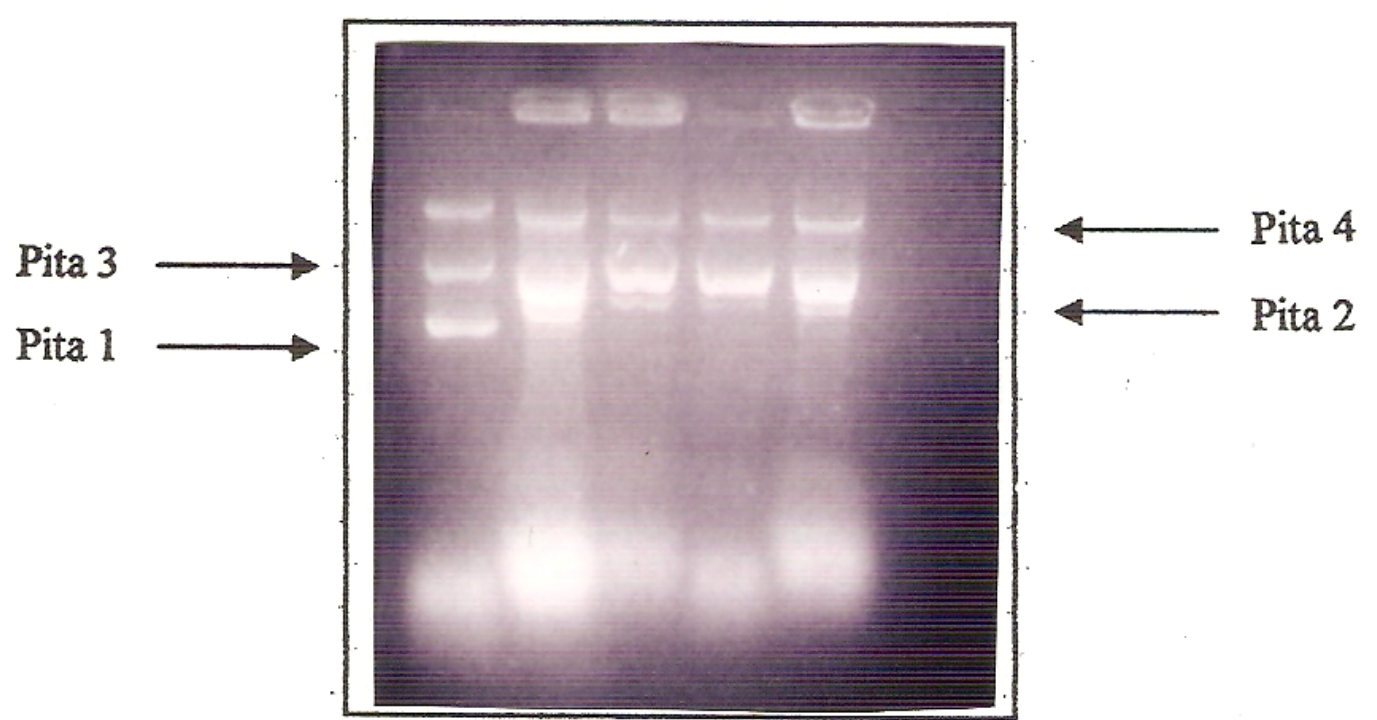

Gambar 2. Elektroforegram hasil uji aktivitas pemotongan DNA superkoil fraksi protein hasil pemurnian dengan kolom CM Sepharose CL-6B yang terikat fase diam. Pita 1: pita DNA superkoil, pita 2: pita DNA linier, pita 3: pita DNA nicked circular, pita 4: pengotor. Lajur a: DNA plasmid pUC18 utuh (kontrol negatif), b dan d: fraksi 7 (72 gg ), c dan e: fraksi 8 (72 ǵg).

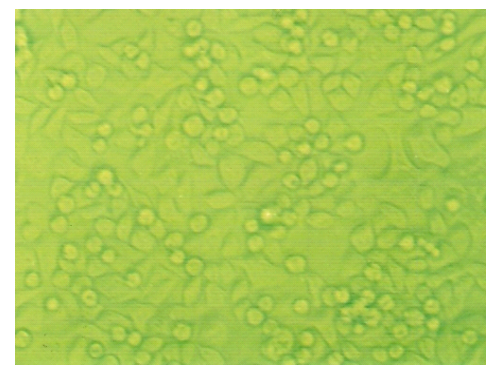

(A)

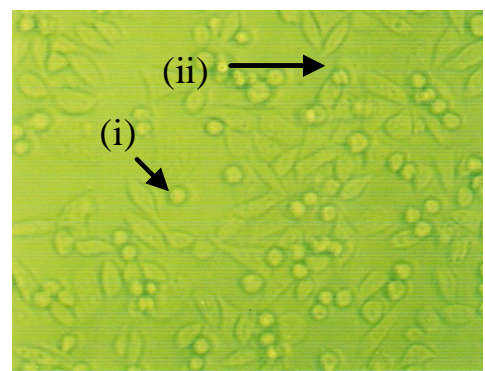

(B)

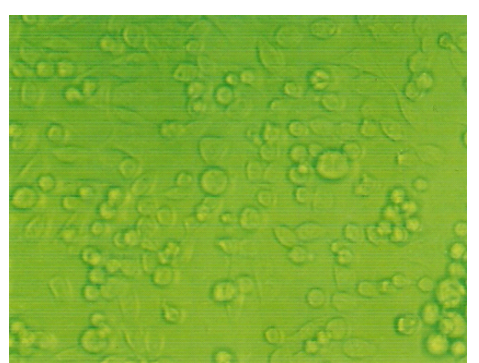

(C)

Gambar 3. Gambaran perubahan morfologi sel HeLa setelah diberi perlakuan dengan fraksi protein hasil pemurnian dengan kolom CM Sepharose CL-6B terikat fase diam yang memiliki aktivitas pemotongan DNA superkoil pada kultur sel HeLa dengan waktu inkubasi selama 24 jam (A) kontrol negatif, (B) kadar protein $0,553 \mathrm{mg} / \mathrm{mL}$, dan (C) kadar protein $0,004 \mathrm{mg} / \mathrm{mL}$. (i) Sel mati, (ii) Sel hidup

Berdasarkan hasil uji aktivitas pemotongan DNA superkoil, diperoleh 2 fraksi mayor yang terikat pada fase diam yang menunjukkan aktivitas pemotongan DNA superkoil yaitu fraksi 7 dan fraksi 8 seperti ditunjukkan pada gambar 2. Fraksi
Selanjutnya dilakukan uji sitotoksisitas fraksi-fraksi protein yang diperoleh pada kultur sel HeLa. Hasil uji sitotoksisitas fraksi protein tersebut ditunjukkan pada Tabel 1 .

Berdasarkan hasil uji sitotoksisitas 
fraksi protein dari daun $M$. jalapa L pada kultur sel HeLa dengan waktu inkubasi 24 jam seperti ditunjukkan pada tabel 1, dapat dilihat bahwa persentase kematian sel HeLa baik pada fraksi protein dialysis, fraksi protein tidak terikat fase diam dan fraksi protein yang terikat pada fase diam yang terelusi dengan dapar natrium fosfat $5 \mathrm{mM}$ $\mathrm{pH} 6,5$ pada gradien $\mathrm{NaCl} 0,33-0,37 \mathrm{M}$ tidak terlalu besar (kurang dari 50\% kematian sel).

\section{Pembahasan}

Berdasarkan data hasil penelitian ini, kadar protein tertinggi adalah pada ekstrak gubal yang disebabkan karena proteinnya masih bercampur dan belum dipisahpisahkan. Protein pada ekstrak gubal dipisahkan lebih lanjut dengan pengendapan menggunakan ammonium sulfat, dilanjutkan dengan dialysis dan pemisahan dengan kromatografi penukar kation menggunakan kolom CM Sepharose CL-6B dan fase gerak dapar natrium fosfat $5 \mathrm{mM}$ pH 6,5 selama 30 menit dengan kecepatan alir $0,8 \mathrm{ml} /$ menit dilanjutkan elusi dengan dapar natrium fosfat $5 \mathrm{mM}$ pH 6,5 yang mengandung natrium klorida 0,5 M secara bergradien selama 90 menit. Dari hasil uji aktivitas pemotongan DNA superkoil diketahui bahwa fraksi protein terikat fase diam yang terelusi dengan dapar natrium fosfat $5 \mathrm{mM} \mathrm{pH} 6,5$ pada gradien $\mathrm{NaCl}$ 0,33-0,37 $\mathrm{M}$ (fraksi 7 dan 8) menunjukkan aktivitas pemotongan DNA superkoil secara sempurna, dimana DNA superkoil berubah menjadi bentuk DNA linier dan nicked circular. Data tersebut menunjukkan bahwa fraksi protein 7 dan 8 yang terikat fase diam memiliki aktivitas biologis sejenis RIPs karena mampu memotong DNA superkoil untai ganda menjadi bentuk nicked circular dan linier. Barbieri et al. (1993) melaporkan bahwa RIPs tipe 1 dimurnikan dengan kromatografi penukar kation dengan fase diam derivate CM (carboxymethyl) atau sulfopropil karena RIPs tipe 1 mempunyai titik isoelektrik (pI) pada daerah alkali, biasanya $=9,5$. MAP yang merupakan RIPs tipe 1 memiliki titik isoelektrik 9,8 (Kubo et al., 1990). Oleh karena itu, pada pemurnian fraksi protein dari daun M. jalapa L. Menggunakan fase diam CM Sepharose CL-6B dan fase gerak dapar natrium fosfat $5 \mathrm{mM} \mathrm{pH} 6,5$, protein-protein yang mempunyai $\mathrm{pI}$ lebih besar daripada $\mathrm{pH}$ larutan akan bermuatan positif. Dengan adanya gugus karboksil pada CM Sepharose
CL-6B maka semua protein yang bermuatan positif akan terikat pada fase diam yang bermuatan negatif tersebut. Sedangkan protein-protein yang bermuatan negatif tidak akan berikatan dengan fase diam dan langsung terelusi keluar dari kolom.

Fraksi protein hasil pemurnian tersebut selanjutnya diuji aktivitas sitotoksiknya pada kultur sel HeLa dengan waktu inkubasi 24 jam. Data hasil uji sitotoksisitas pada sel HeLa seperti tercantum pada tabel 1 menunjukkan bahwa persentase kematian sel HeLa setelah pemberian fraksi protein relatif kecil yang menunjukkan bahwa fraksi protein dialisis, fraksi protein tidak terikat fase diam dan fraksi protein terikat fase diam dengan kadar $0,553 \mathrm{mg} / \mathrm{mL}$ relatif tidak toksik terhadap sel HeLa pada waktu inkubasi 24 jam. Diantara ketiga fraksi protein tersebut, fraksi protein hasil pemurnian yang terikat pada fase diam dan terelusi pada gradien $\mathrm{NaCl} 0,33-0,37 \mathrm{M}$ dan 0,38-0,41 M menunjukkan aktivitas sitotoksik paling tinggi dengan persentase kematian sel HeLa sebesar 29,23\%. Hal ini kemungkinan disebabkan karena fraksi ini hanya mengandung protein yang benar-benar aktif. Gambaran morfologi sel Hela setelah pemberian fraksi protein terikat fase diam yang terelusi pada gradien $\mathrm{NaCl} 0,33-0,37$ $\mathrm{M}$ dan 0,38-0,41 M (gambar 3) menunjukkan bahwa pada pemberian protein dengan kadar 0,553 dan $0,004 \mathrm{mg} / \mathrm{mL}$ populasi sel $\mathrm{HeLa}$ yang hidup lebih sedikit dibandingkan dengan kontrol negatif. Hal ini menunjukkan bahwa meskipun fraksi protein tersebut dengan kadar tertinggi $0,553 \mathrm{mg} / \mathrm{mL}$ relatif tidak toksik terhadap sel HeLa, tetapi terjadi penghambatan proliferasi sel HeLa.

\section{Kesimpulan}

1. Fraksi protein yang memiliki aktivitas sejenis RIPs, yang dimurnikan dari daun Mirabilis jalapa L. dengan kromatografi penukar kation menggunakan kolom $C M$ Sepharose CL-6B, menggunakan fase gerak dapar natrium fosfat $5 \mathrm{mM} \mathrm{pH} 6,5$ selama 30 menit dengan kecepatan alir $0,8 \mathrm{ml} /$ menit dilanjutkan elusi dengan dapar natrium fosfat $5 \mathrm{mM} \mathrm{pH} 6,5$ yang mengandung natrium klorida $0,5 \mathrm{M}$ secara bergradien selama 90 menit, terelusi pada gradien natrium klorida 0,33 - 0,37 $\mathrm{M}$ dan $0,38-0,41 \mathrm{M}$

2. Fraksi protein aktif sejenis RIPs hasil pemurnian dengan kolom CM Sepharose 
$C L-6 B$ pada kadar $0,553 \mathrm{mg} / \mathrm{ml}$, bersifat relatif tidak toksik terhadap kultur sel HeLa dengan persentase kematian sel HeLa sebesar 29, 53\%.

\section{Pustaka}

Barbieri, L., Batteli, M.G., Stirpe, F. (1993) Ribosome Inactivating Protein from Plants, Biochem et Biophysica Acta, 405-410

Elly, W. (2002) Efek Fraksi Protein yang Diisolasi dari Daun Mirabilis jalapa L. terhadap Proses Apoptosis pada Sel HeLa, Skripsi, Fakultas Farmasi Universitas Gadjah Mada, Yogyakarta

Habuka, N., Murakami (1991) Amino Acid Sequence of MAP, Total Synthesis of Gene an Expressionin E. coli, Journal Biol. Chem, 264

Herawati, T. (2002) Pemurnian Ribosome Inactivating Protein (RIP) dari Daun Mirabilis jalapa L. Bunga Merah menggunakan Kolom Sephacryl S300 HR. Skripsi. Fakultas Farmasi Universitas Gadjah Mada, Yogyakarta

Heyzer, E.G., Gan, Sulistia, Nafrialdi (1987) Antikanker, in Sulistia Gan et al., Farmakologi dan Terapi, Edisi III, Fakultas Kedokteran Umum Universitas Indonesia, Jakarta, 624625

Kubo, S., Ikeda, T., Imaizumi, S., Takanami, Y., Mikami, Y., 1990, A Potent Plant Virus Inhibitor Found in Mirabilis jalapa L., Ann Phytopathol Soc Jpn, 56, 481-487

Prasetyowati, A.T., 2002, Uji Aktivitas NGlikosidase Daun Bunga Pukul Empat (Mirabilis jalapa L.) Bunga Merah dari Hasil Pemurnian denagn Kromatografi Kolom CM Sepharose, Skripsi, Fakultas Farmasi Universitas Gadjah Mada, Yogyakarta

Sari, R.P., 2002, Efek Fraksi Protein Sejenis Ribosome Inactivating Proteins (RIP) yang Diisolasi dari Akar Mirabilis jalapa L. terhadap Proses Kematian Sel Raji, Skripsi, Fakultas Farmasi Universitas Gadjah Mada, Yogyakarta

Vivanco, J.M., Qurci, M., Salazai, L.F., 1999, Antiviral and Antiviroid
Activity of MAP-Containing Extract from Mirabilis jalapa L. roots, Plant Dis, 83, 11161121 